\title{
DIFFICULTIES IN THE MACHINING SUPER DUPLEX STAINLESS STEELS
}

\author{
András István NAGY, ${ }^{1}$ Enikő Réka FÁBIÁN, ${ }^{2}$ Richárd HORVÁTH, ${ }^{3}$ Pal TEREK ${ }^{4}$ \\ 1,2,3 ÓbudaUniversity, Donát Bánki Faculty of Mechanical and Safety Engineering, Budapest, Hungary \\ ${ }^{1}$ nagy.andras.istvan@hotmail.hu \\ ${ }^{2}$ fabian.reka@bgk.uni-obuda.hu \\ ${ }^{3}$ horvath.richard @bgk.uni-obuda.hu \\ ${ }^{4}$ Faculty of Technical Sciences, University of Novi Sad, Serbia, palterek@uns.ac.rs
}

\begin{abstract}
Super duplex stainless steels are used in increasingly more areas. The machinability of duplex stainless steels is generally poor. We performed dry turning tests on G X2CrNiMoCuN 26-6-3-3 casted superduplex steel, using two different PVD coated cutting inserts. One of them was coated with TiAlN and other with TiAlSiN. Strong burr and built-up edge formation were observed during our machining experiments; these damaged the edges of the tools. The shortened tests did not show significant difference betwen the effect of the coatings.
\end{abstract}

Keywords: duplex stainless steel, machinability.

\section{The history and application of duplex steels}

Duplex stainless steels (DSS) appeared in the first quarter of the 20th century, but low-carbon steels could not be produced economically with the metallurgical processes of the time. The solution was AOD (Argon-Oxigen Decarburization). It allowed the manufacturing of steels with $0.01 \%$ $0.03 \%$ carbon content economically, which was necessary for retaining adequate corrosion resistance. Most stainless steels used in the industry have an austenite structure, but modern duplex steels are also gaining ground, due to their good mechanical properties, such as high strength and good impact strength even at low temperatures [1].

Duplex steels are used in numerous areas of insutry, such as the chemical industry, the oil industry and the machine industry. Entire ship and bridge structures have been produced from a duplex stainless steel [1]. Duplex steels perform well in chloride environments as well, and can be used to make machine parts subjected to cavitation.
The microstructure of duplex steels is generalyly $50 \%$ austenite and $50 \%$ ferrite. The ferrite part accounts for the good stress corrosion resistance and high strength, while the austenite part provides toughness and good pitting corrosion resistance.

Thanks to the good mechanical properties of DSS steels, parts made from it can be smaller (require less steel), which indirectly reduces carbon dioxide emissions, an important requirement nowadays (Figure 1.).

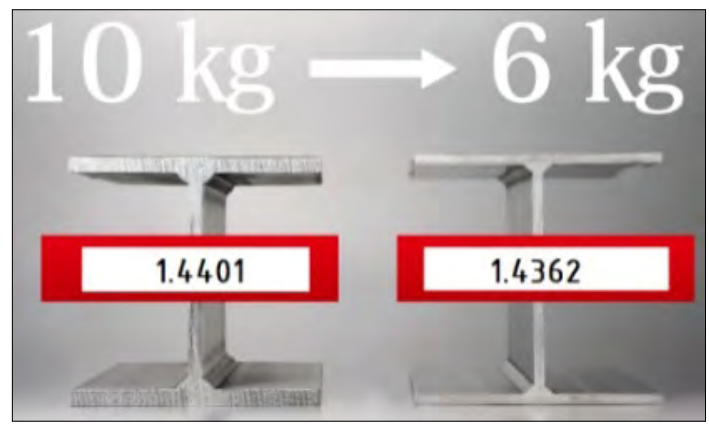

Figure 1. Comparison of 1.4401 austenite steel and 1.4362 duplex steel with the same load-bearing capacity [2] 
Stainless steels are grouped according to their PREN (pitting index) [3].

$$
P R E_{N}=\operatorname{Cr}(\%)+3,3 \cdot M o(\%)+16 \cdot N(\%)
$$

Based on the pitting index, there are lean, normal duplex $\left(P R E_{N}=25-38\right)$, super duplex (SDSS) $\left(38<P R E_{N}<48\right)$ and hyper duplex steels $\left(48<P R E_{N}\right)$ [3]. A higher $P R E_{N}$ index means better corrosion resistance.

As more and more DSS steels are used, their processing technology is also researched more and more. An essential technology is machining, which provides adequate accuracy for fitted parts. Good surface quality is not only a question of aesthetics but also influences the lifetime of the part. Surface quality also affects resistance to fatigue and corrosion loading. For this reason, research into machining is important: it helps determine the proper technological parameters.

\section{The main machining problems of duplex steels}

The machining of duplex stainless steels poses several problems. Similarly to austenite steels, they produce long chips, which is uneconomical from the point of view of chip manipulation. Long chips mean machining cannot be left unattended, and they can be wound on the part and thus impair surface roughness and cause aesthetic problems. Flash can injure the operator and its removal means an extra phase, thus increasing costs.

The relative machinability of duplex steels is worse than that of single-phase, ferrite, martensite or austenite corrosion-resistant steels [4].

When DSS steels are machined, the tools are subjected to different loads. Since DSS steels are highly alloyed and have a ferrite structure, the tool is subjected to large forces, which increases the probability of damage. Abrasive wear is increased by a built-up edge. The chip adhering to the tool and removal is repeated cyclically, causing adhesion wear, which changes operating angles and thus introduces extra vibration into the system. Broken-off chips can stick back to the surface, which makes the manufactured part unusable. The characteristic picture of wear on the tool is edge wear-according to the literature, this is caused by the hardening tough materials [5]. Also, based on the literature, an AlTiN nano-coating applied with the PVD process, performed well in the machining of duplex steels [5].

\section{Materials and methods}

\subsection{The duplex steel used in the experiment}

The selected super duplex steel was G X2CrNiMoCuN 26-6-3-3 cast steel quality, according to MSZ EN 10 027-1. It is often used as the material of pump cases and other parts, because of its excellent resistance to cavitation and corrosion. Its designation is 1.4517 according to MSZ EN 10 027-2. Table 1. shows the characteristic composition of the steel.

Table 1. Usual composition of 1.4517 steel

\begin{tabular}{|c|c|c|c|c|c|}
\hline $\mathbf{C}, \%$ & Cr, \% & Ni,\% & Mo, \% & N, \% & Cu, \% \\
\hline $\begin{array}{r}\max \\
0.03\end{array}$ & 26 & 6 & 3 & 0,2 & 3 \\
\hline
\end{tabular}

After casting, the $\sim 50-50 \%$ austenite-ferrite microstructure was obtained by heat treatment (Figure 2.).

\subsection{The tools used in the experiment}

Machining was a turning experiment. The insert used was CNMG 12-04-08M, the tool holder was PCLNR 25-25-12. Using literature data, we applied two kinds of coatings on the inserts with the PVD process: one was a TiAlN coating and the other a TiAlSiN coating. Both coatings, nano-coating with a layer thickness of $2 \mu \mathrm{m}$. The TiAlN coating is greyish, with a hardness of $\sim 3200 \mathrm{HV}$, and can resist oxidation up to $750{ }^{\circ} \mathrm{C}$ during machining. The TiAlSiN coating gives the insert a bronze colour. Its hardness is $\sim 4000 \mathrm{HV}$ and protects the material of the insert from oxidation up to $800^{\circ} \mathrm{C}$; this makes it suitable for high-speed machining.

\subsection{Machining environment, examined pa- rameters}

We performed machining dry because it is more cost-effective and also more environmentally friendly. The long chips we obtained were damaged on the sides (Figure 3.).

We used constant cutting speed $\left(v_{c}=70 \mathrm{~m} / \mathrm{min}\right)$ and feed $(f=0.15 \mathrm{~mm})$, so that we could differentiate between the performance of the coatings with a shortened test.

In both cases, we experienced heavy wear after 5 minutes of cutting. The wear types characteristic to the group appeared, such as heavy edge wear, the formation of a built-up edge (Figure 4.), which also affected surface quality, and long chips which wound around the workpiece easily. After machining, we found thick hard flash on the side of the workpiece. This flash was not only problematic from a workpiece handling aspect 


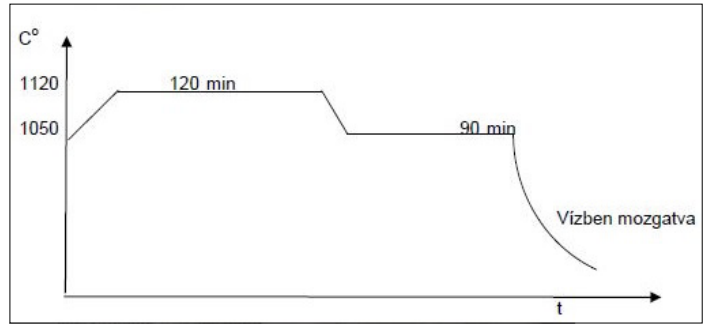

Figure 2. The heat treatment diagram of the specimen

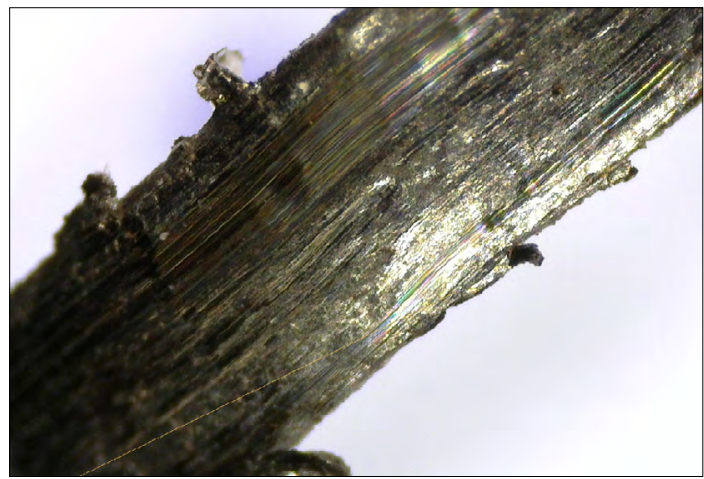

Figure 3. The back of a chip (stereo microscope image)
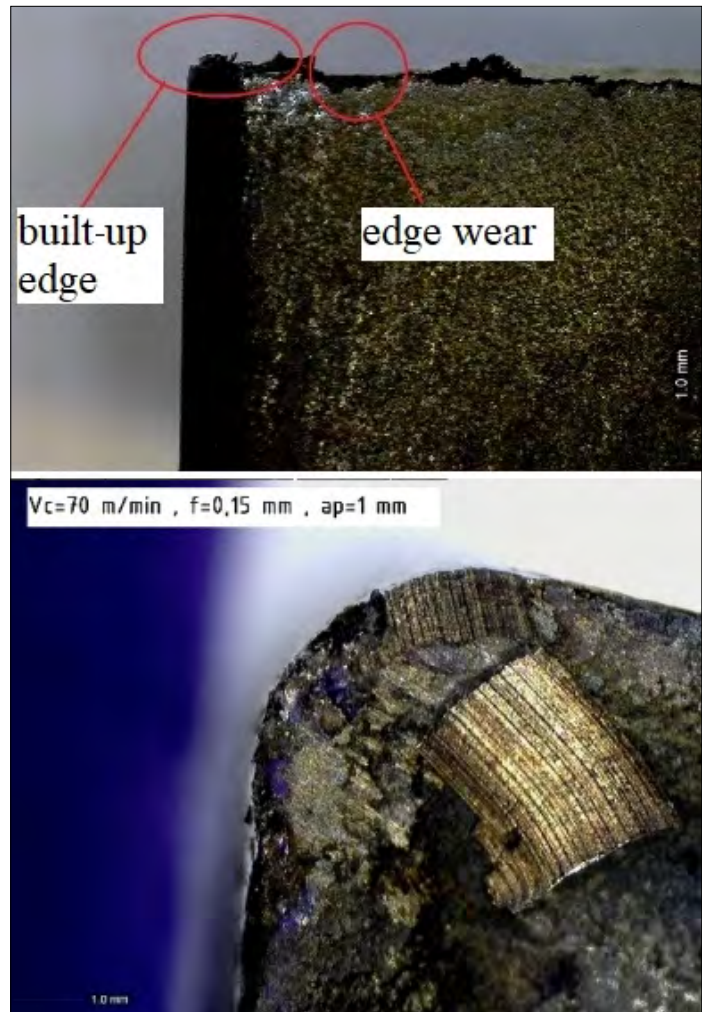

Figure 4. Characteristic wear types caused by duplex stainless steel; a) TThe wear of the TiAlN insert b) Built-up edge on the TiAlN coated insert (Stereo microscope image)

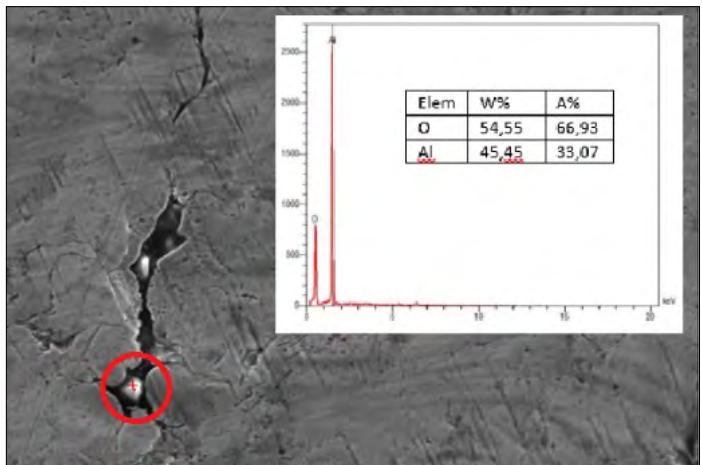

Figure 5. $\mathrm{Al}_{2} \mathrm{O}_{3}$ contamination near the particle boundary

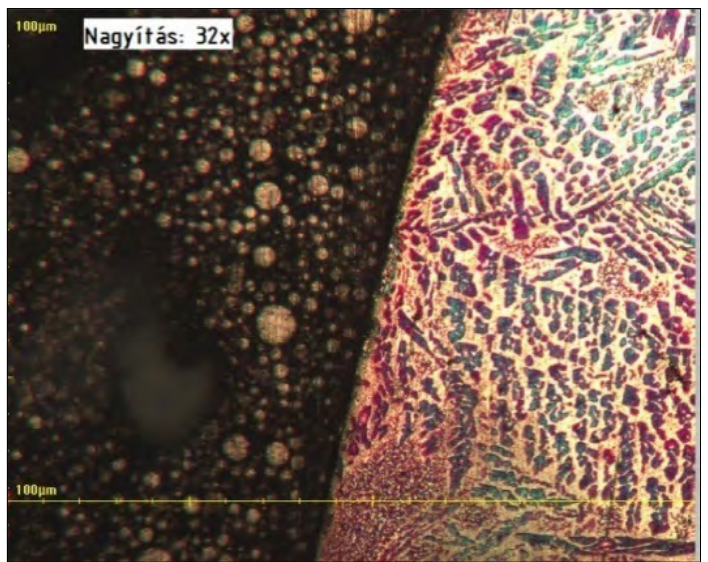

Figure 6. The etched microstructure of a specimen (axial cross-section)

but also had an adverse effect on the edge of the insert. We did not experience considerable difference between the effects of the coatings during the shortened test.

The diffusion effect of temperatures during cutting can start precipitation. The high copper content of the examined SDSS steel, and its precipitations in the given temperature range [1, 3 , 6] presumably increase tool wear. When we analyzed the chip pattern with a scanning electron microscope, we found an $\mathrm{Al}_{2} \mathrm{O}_{3}$ particle in one of the cavities near the particle boundary (Figure 5.). This is probably a particle remaining after the deoxidation of the steel. $\mathrm{Al}_{2} \mathrm{O}_{3}$ is used as the material of abrasive tools as it is very hard; in turning and milling, it damages the tool, wearing it by abrasion..

As can be clearly seen in Figure 6. the workpiece was heat-treated excellently; its microstructure is fine and uniform even near the surface. When the prepared cross-sectional sample was etched with the Beraha 2 reagent, the uniform dispersion of 
the heavily discoloured and non-discoloured austenite-ferrite amount was clearly visible. It can also be seen that near the turned surace, there is no considerable structural distortion.

\section{Summary}

We experienced several types of wear during the dry cutting of duplex stainless steel. Depending on the composition of the PVD coating, a builtup edge can form, which can be reduced based on the manufacturer's recommendations or recommendations in the literature, for example by increasing cutting speed. The shortened tests did not show considerable difference between the performance of the two coatings. $\mathrm{An}_{2} \mathrm{Al}_{3}$ particle lodged in at the szemcsehatár can increase the wear of the insert. The tough material structure results in increased flash formation.

\section{Acknowledgement}

The authors wish to thank Magyarmet Finomöntöde Kft. for casting and heat-treating the workpieces for the experiment, and TeMA Tehetség Menedzsment Alapítvány for its support.

The experiments were performed with the support of the New National Excellence Program of the Ministry of Human Capacities codenamed ÚNKP-18-IOE-37, and the project EFOP-3.6.1-16-2016-00010.

\section{References}

[1] Bödök K.:Az ötvözetlen, gyengén és erösen ötvözött szerkezeti acélok korrózióállósága, különös tekintettel azok hegeszthetőségére. Corweld, Budapest, 1997. 225-252.

[2] Nippon Steel \& Sumikin Stainless Steel Corporation

https://nssc.nssmc.com/en/campaigns/duplex/ orientation/nssc2120.php

[3] Gunn R. (Ed.).: Duplex stainless steels: microstructure, properties and applications. Woodhead Publishing. 1997. 6-7.

[4] Samdvik Coromant, Tudástár

https://www.sandvik.coromant.com/hu-hu/ knowledge/materials/pages/workpiece-materials.aspx

[5] de Paiva J. M., Torres R. D., Amorim F. L., Covelli D., Tauhiduzzaman M., Veldhuis S., Fox-Rabinovich G. Frictional and wear performance of hard coatings during machining of superduplex stainless steel. The International Journal of Advanced Manufacturing Technology, 92/1-4. (2017) 423-432. https://doi.org/10.1007/s00170-017-0141-4

[6] The Outokumpu Handbook of Stainless Steel, 2018.75

https://otk-sitecore-prod-v2-cdn.azureedge.net/-/ media/from-sharepoint/documents/product/outokumpu-stainless-steel-handbook.pdf?revision 